\title{
SOME CONTRIBUTIONS OF HABERMAS TO THE STUDY OF PUBLIC COMMUNICATION OF SCIENCE ${ }^{1}$
}

\author{
Ana Eliza Ferreira Alvim-Silva ${ }^{2}$ \\ José Roberto Pereira ${ }^{3}$ \\ Cibele Maria Garcia de Aguiar ${ }^{4}$
}

\begin{abstract}
This theoretical essay explores three publications by Jürgen Habermas from the 1960s. The author deals with the critique of science, the production of knowledge and universities democratization. The objective was to extract from them clipings of reflections that can contribute to the studies of public communication of science. We consolidated the considerations into a graphic representation that summarizes the factors to be considered when thinking about the practice of science communication in society: the importance of considering the three interests that drive the production of knowledge - technical, practical and emancipatory, of promoting self-reflection of sciences in politicized and democratized universities, and the mediation of society in the interaction between science and politics, to subsidize decision-making based on social interests. We argue that the basis for a public communication idea of dialogical science - now widely defended - emerged in the German philosopher's thinking in books published more than 50 years ago. However, that was not his central motivation at that time.
\end{abstract}

Keywords: Public communication of science. Jürgen Habermas. Social participation. Policy decision.

${ }^{1}$ This work was suported by the Minas Gerais State Agency for Research and Development [Fundação de Amparo à Pesquisa de Minas Gerais - FAPEMIG, under Grant APQ-04177-15.

2 Journalist, University Communications, Federal University of Lavras (UFLA), Lavras, MG - Brasil. (D) http://orcid.org/0000-0001-8602-6946. E-mail: anaeliza.alvim@ufla.br.

${ }^{3}$ Full Professor, Graduate Program in Administration, Federal University of Lavras (UFLA), Lavras, MG - Brasil. (D) https://orcid.org/0000-0003-1570-2016. E-mail: jrobertopereira2013@gmail.com.

${ }^{4}$ Graduate Programme in Science and Technology Policy, University of Campinas (UNICAMP), Campinas, SP - Brasil. (DD https://orcid.org/0000-0002-2416-9818. E-mail: cibele.aguiar@yahoo. com.br.

https://doi.org/10.1590/0101-3173.2021.v44n4.02.p21

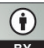

This is an open-access article distributed under the terms of the Creative Commons Attribution License. 


\section{INTRODUCTION}

From the second half of the 19th century, efforts to spread science in society began to intensify in Brazil, mainly in response to the belief that science could contribute to technical and industrial progress. In the 20th century, activities based on the idea of democratizing science and social inclusion were also initiated. The movement to support the so-called scientific divulgation has oscillated between periods of greater and lesser effervescence throughout Brazil's history and has been at a high since the 1980s (MASSARANI; MOREIRA, 2016). Recent evidence since the 2000s includes creating specific government structures to address the popularization of science calls for applications from research funding agencies to encourage the practice, opening new venues for science, and an increased number of events in the area (MENKES, 2012). Recently, a study carried out with research institutes in universities and major scientific institutions in Brazil, Germany, Italy, Japan, the Netherlands, Portugal, the United Kingdom, and the United States showed that Brazil today has a more intense public communication of science than other countries, with more actions in the traditional media, in the new media and scientific dissemination events (ENTRADAS et al., 2020).

Considering the increasing interest in the issue, this theoretical essay seeks to systematize contributions from German philosopher Jürgen Habermas's writing to encourage reflection on science's public communication. Habermas's report related to the public sphere, his Theory of Communicative Action (TCA) and his Discourse Theory of Law and Democracy provides rich theoretical material for thinking about the challenges that surround the topic. However, this article is exclusively devoted to analyzing how "Technology and Science as Ideology", "Toward a Rational Society" and "Knowledge and Human Interests," written between 1968 and 1969, can contribute to this area's reflections. It is an analysis that cuts the author's production, selecting three works from the 1960s published very close to each other, and that discuss science, knowledge production and the democratization of universities (which, in the case of Brazil, our study context, are institutions of significant expression of scientific output, specifically public universities, whose activities are based on the pillars of research, teaching and extension).

These works are interconnected, as they are related to the critique of science. Some reflections can be used to think about science's public communication (and we decided to extract from them clippings that specifically reflect on the public communication of science). We argue that several of the ideas contained in these writings provide rich material for 
researchers embarking on the challenge of academic research on the topic and therefore represent an opportunity to expand the topic's theoretical grounds.

In Brazil, many studies on public communication in its broadest sense already appeal to the German author's ideas, especially concerning contributions on communicative action and public spheres. It is the case of Brandão (2007) writings and Nobre and Gil (2017), for example. Therefore, when we talk about public communication of science, it is also beneficial considering the author's reflections and recovering, in his set of works, those ideas and excerpts that can support the discussions on the practices of popularization of knowledge. It is what we seek to do in this article, in which the proposal was to reflect on how three works written more than 50 years ago, mobilized by the critique of science in different aspects, bring helpful considerations to researchers concerned with the issue, and can be considered in the formulation of policies aimed at popularizing science and in proposing new research problems involving the theme.

The thinking that prevailed in the nineteenth century - that science could enter everyday life through only two paths: the technical use of scientific information and students' individual education -is now behind us. Habermas makes this reflection in 1968, arguing that the circulation of scientific knowledge cannot occur solely in the sphere of individual training but also requires a politically significant process of "translating" (HABERMAS, 1968, p. 97) knowledge to the social context through language. Thus, even without focusing on science's public communication, Habermas already lays essential groundwork for future reflections on this issue of public interest.

We begin this essay with a summary of related topics addressed by current studies, particularly concerning the public's position in science's public communication. Next, we analyze Habermas' three books, examining the interconnection of part of the writings with our topic of interest. We conclude by systematizing the ideas extracted from the three books in a graphical representation. This representation summarizes the factors that, based on the works, we propose to be considered when thinking about the practice of science communication in society. 


\section{CURRENT STUdiEs AND PERSPECTIVES: THE VISION OF THE PUBLIC}

Although we consider that there is a subtle difference between the term's popularization of science and public communication of science (Silva, 2019), in this study, we use both expressions with the same purpose: that of considering the communication of science done in an essentially dialogical way with the public.

We follow Germano and Kulesza (2007, p. 21), who argue for the use of the term popularization of science over other phrases, such as scientific dissemination, popularization of knowledge or scientific literacy. "Scientific knowledge is the most effective form of power we can invent. It is not fair, nor safe, for it to be in the hands of only a few nations or individuals", the authors argue. We observe that the term "popularization of science" is more connected to the universe of emancipatory cultural actions, based on Paulo Freire's ideas (who advocates a dialogical and problematizing concept of the educational act). Considering communication as a reflective and horizontal sharing and dialogue process, we believe that the expression "popularization of science" best expresses this idea.

Popularization presupposes that scientific material is being placed "in the field of popular participation and under the scrutiny of dialogue with social movements. It is converted to the service and causes of the oppressed majorities and minorities in a cultural action that [...] guides their actions, respecting daily life and the symbolic universe of the other" (GERMANO; KULESZA, p. 20).

On the other hand, we also consider the definitions of Nobre and Gil (2017) about the term public communication. For them, actions that prioritize enunciators from the civic spheres and those historically considered illegitimate can be called public communication. Public communication of science, under this view, would go beyond practising the notions of dialogue, interaction, sharing, respect for the symbolic universe of the other and coparticipation in the construction of knowledge encompassed by the term popularization of science: it would require that the communication produced be guided due to the demands and interests of the public itself, which should appear as a protagonist in the generation of the guidelines for science messages. As the excerpts extracted from the works analyzed in this study serve to think about both perspectives - popularization and public communication 
of science - as they necessarily involve dialogue, we consider both expressions in our reflections.

Discussions on the public communication of science, or popularization of science, have a long history. However, in relatively recent times, the number of published academic studies has been increasing based on the records found in the international database Web of Science. A search using the area's main keywords reveals that the majority (almost 90\%) of the scientific articles on the topic have been published since 2010 . However, the first was published in the 1960s. This production often discusses models for the public communication of science that have been adopted over time, ranging from those that regard the public as passive and ignorant, i.e., a mere receiver of information similar to a blank piece of paper, to those that suport dialogism and the consideration of popular knowledge and its values in the popularization of science process (KATONITTA; MAEDA; IWAHASHI; TACHIKAWA, 2018; MYERS, 2003; BAEUR, 2007; GREGORY et al., 2007; STILGOE; LOCK; WILSDON, 2014; MAKAROVS; ACHTERBERG, 2018; JASANOFF, 2014; NISBET; SCHEUFELE, 2009; BURNS; O'CONNOR; STOCKLMAYER, 2003; FRIESIKE; SCHELIGA; PUSCHMANN; FECHER, 2016; DIETZ, 2013).

There is an opposition between what many refer to as the "deficit model," which presupposes an ignorant public that must be informed in a unidirectional flow from science to the citizen (RÖDDER, 2015) and dialogical practices on the level of democratic citizenship and egalitarian pluralism. This second concept can be managed through dialogue in which the actors are communication partners, which demands a change in traditional hierarchies of knowledge. Pieczka and Escobar (2012) noted genuine attempts to engage in deliberative dialogues but also found evidence that dialogue has merely been used as a sophisticated tool for managing public perceptions. They conclude that the scientific community is rooted in unidirectional communication practices even as it uses rhetorical features of dialogue that are still considered vague, misunderstood and difficult to operationalize.

Thus, an important point emphasized in recent years is a change in perception regarding the public. Stilgoe and Wilsdon (2014), Owens (2000) and, particularly, Jasanoff (2014) (the latter in her renowned study "A mirror for science") note the narrow framework and erroneous assumption that science is divided into publics separated by walls of ignorance and indifference. In their opinion, this prejudiced view of the public has resulted in inefficient public policies. 
A public imagined as ignorant and hostile was the impetus for many of the science communication activities in the 1980s and 1990s, and though this transformed into more sophisticated ideas of engagement with multiple 'publics' for science and technology, such publics were often still imagined as 'concerned', 'anti-scientific' or 'obstructions' to innovation (House of Lords, 2000; Owens, 2000). (STILGOE; WILSDON, 2014, p. 7).

We propose that these discussions,-present in publications on democratizing perspectives for the public communication of science, concentrated in the second decade of the twenty-first century,-can benefit from considering writings from the 1960s by a classic author in communication studies: Jürgen Habermas. While not primarily concerned with discussing the popularization of science, Habermas develops reflections that may be appropriate for those studying the issue. However, it is rare to find Habermas referenced by those writing on the topic. Searching published articles on science journalism, the popularization of science and related expressions on the Web of Science, we found more than 1,300 records, of which approximately $1.6 \%$ mention terms that are central for Habermas (i.e., public sphere, theory of communicative action, system and life-world or mention Habermas's name) in the main topic. Only six of these articles include Habermas in the list of references. Even in these cases, the authors only turn to Habermas in specific situations, quoting him only briefly and without any intention of using his research as a foundation for more detailed reflection on science's popularization.

\section{HABERMAS'S REFLECTIONS AND SOME CONTRIBUTIONS TO THINKING ABOUT THE PUBLIC COMMUNICATION OF SCIENCE}

As De Lima (2009) observes, Habermas advocates a third means of control for society as an alternative to bureaucratization and to monetization (i.e., power and money, respectively), which have had many unwanted effects, such as the arms race, including the development of nuclear weapons; the impoverishment of developing countries; unemployment; social imbalances; and the burden on the environment. Habermas (2012) proposes solidarity, through which the formation of political will must be assured. Through language, argumentation and intersubjective understanding, citizens can act cooperatively as the protagonists of dialogues and debates capable of supporting political decisions and normative regulations. 
However, before we advance further into these propositions, which are closely connected to Habermas's Theory of Communicative Action, we should note that the philosopher presented reflections in his early works that are also useful to the public's discussion of communication of science. These works are from the 1960s, and to a certain extent, their ideas appear in recent studies on the public communication of science. However, going back in time via Habermas can enrich the theoretical component of the discussion.

\subsection{KNOWLEDGE AND Human INTERESTS AND ITS CONTRIBUTIONS}

Habermas's (1987) fundamental thesis in Knowledge and Human Interests (originally published in 1968) is that all knowledge is set in motion by interests that guide and direct it, an idea that undermines the alleged impartiality of the scientific method. Interests precede self-reflection (there is no knowledge without interest) and obscure the vaunted "objectivity of knowledge." For Habermas, the interest that lies at the root of knowledge affects the possibility of knowledge as such. Therefore, the dynamic of knowledge generation occurs through the satisfaction of underlying interests: a) Technical interest motivates the natural, empirical-analytic sciences, which seek to predict and control facts and primarily produce information; b) Practical interest represents the foundation of the spirit's sciences, which are focused on social understanding through communication and interaction, resulting mainly in interpretations; c) Emancipatory interest motivates critical science, which can reflect on the knowledge it produces, thus reclaiming the role of philosophy in the scientific process and producing knowledge capable of social transformation in which analyses are prioritized as a category of knowledge. Although contradictory, these interests are interlinked and must be considered together. As Paes de Paula (2016, p. 37, our translation) explains,

Emancipatory interest on its own becomes criticism for the sake of criticism, as it depends on practical and technical interests to become actions; practical interest in isolation tends to transform into pure understanding and description, as it needs technical and emancipatory interests to be capable of affecting reality; and technical interest alone becomes instrumentalism, as it is also necessary to consider the social necessities of understanding and emancipation.

Habermas (1987) criticizes technicism and scientism, which in his perspective have reduced all human knowledge to the domain of the technical 
and the model of the empirical sciences, limiting the field of action of human reason. He thus criticizes the structure of the objectivist sciences that deny selfreflection as a foundational element of knowledge construction, considering that all knowledge is objectivity based on interests. Habermas (1987) cites Peirce and Dilthey to locate a particular interception of reducing knowledge theory to scientific theory. These thinkers made advances toward a selfreflection of the natural sciences and the sciences of the spirit. Thus, practical interest appears as another type of interest capable of mobilizing knowledge. Habermas (1987) mobilizes the hermeneutic sciences, the spirit sciences, focused on human interaction and communication through understanding. He asserts that praxis must be accompanied by the theory that concerns it. Knowledge demands reflection. That is, it demands that a person know the "how" and "why."

Causal explanations (which rely on empirical-analytic knowledge) can be converted into technically exploitable knowledge, and narrative explanations (based on hermeneutic knowledge) can be converted into practical knowledge. Thus, while the natural sciences use an investigatory process that occurs within a framework of instrumental activity with nature viewed as an object of knowledge based on technical availability, the spirit's sciences' research process occurs on the level of the activity inherent to communication, through interaction. The cognitive interest that guides the sciences of the spirit is the practical one.

Habermas's (1987) argument defends the importance of the third type of interest, emancipatory interest, which determines the critical sciences. The reflective process causes knowledge to no longer be attached to particular situations (or topics) and be free for new reflections. Thus, knowledge dissociates itself from the conditions that enabled it and served new reflections. However, the initial conditions that gave rise to knowledge do not lose their importance in knowledge production.

Habermas (2011) wrote the text "Nach dreißig Jahren: Bemerkungen zu Erkenntnis und Interesse" (After thirty years: notes on Knowledge and interest), saying that, when rereading the work, he did it with a strangeness, evaluating that there was a particular unproductive character in the discussions and reporting the option to dedicate himself to substantive issues of communicative action theory. Despite the limitations recognized by the author, we believe that the reflections help us project a look at the challenge of discussing science in society. We argue that, by valuing practical and 
emancipatory interests, we can stimulate the popularization of science and, consequently, collaborate so that science starts to incorporate the interests arising from public debate, continuously improving. Let us see: certainly, the development of a particular crop protection product, for example, was driven by a technical interest to eliminate pests that hinder cultivation. However, there is also a social need for understanding, a practical interest that needs to be addressed. Thus, the producer who has access to the pesticide needs to understand the product, how it works, why it should be applied in one way and not another, and the unwanted effects. There is also a need to analyze this information critically: do the benefits outweigh the risks that the use of the product will bring? What are the long-term consequences? Is there any human or natural good that is being harmed from use (health, environment)? Couldn't technical interest be served in any other way? Thus, based on the combination of these interests, we can eliminate the focus on technicality and guarantee the sciences' self-reflection. Indeed, all of these questions can and should be asked in pairs by the scientists themselves. However, it would be, at the very least, inconsistent to exclude society from these reflective processes since science works to generate knowledge to help advance society in its multiple aspects.

Fairclough and Fairclough (2012, p. 31), defending that deliberation and public debate need to be strengthened, recall that the critical process of probing and testing proposals reduces the impact of limited rationality, leading specialists to secure ways of thinking and reasoning. Human fallibility means that an individual alone has a limited capacity for knowledge and imagination. When several citizens come together in the evaluation, the chance of a good decision is more significant since the set of knowledge and future projections' capacity will be enhanced. When sharing information with society, considering practical and emancipatory interests, we can understand that science is open to improvement.

When there is an exclusive focus on the technical interest that mobilized scientific research, it is possible that the public communication of its results will not be made or, if done, it will not be done in order to contemplate the social needs of understanding and emancipation, which require interpretations and analyzes. Thus, considering the theoretical reflections of "Knowledge and Interest" draws attention to the need to popularize scientific knowledge, to do it in a way that encourages interpretations and analyzes and, ultimately, draws attention to the importance of the humanities and in this process. 
Science loses the opportunity to improve its processes based on social participation and is subject to a loss of credibility when its focus is only on technical interest. A particular technology, not subject to public discussion, ends up causing a negative impact on social life.

We then argue that, as research studies encounter space for their debate in the public sphere-through popularization-researchers can incorporate comments, positions, expectations, critiques and statements from the public in their pre-understood research universe. This approach represents a way of providing feedback to the interests that move academia in a participatory manner, which may result in a) technical production more suited to the demands of society, b) more significant contribution to the processes of communication and interaction and, particularly, and c) more substantial development of critical science, which reflects on the knowledge generated and moves toward the possibilities of social transformation. Thus, popularization can contribute to advancing the technical sciences, the sciences of the spirit and the critical sciences simultaneously.

Regarding the critical sciences, we can understand the popularization of science as a process that shares specific information from a scientific study with the public and that this initiative can encourage broader reflection that transcends the study itself. The knowledge produced can then be detached from the specific case that mobilized it to integrate a broader cultural archive, resulting in new reflections and serving the emancipatory interest. Even if it has been mobilized by the technical interest, reflecting on a specific scientific study can be understood as a precondition for more profound, more transformative knowledge.

A fundamental point when considering the mobilizing interests of knowledge is undoubtedly the fact that activities undertaken to popularize science must move away from the mistaken position of depicting science as impartial, free of conflicts and providing absolute and unquestionable explanations. All activities must be guided by the perception that scientific productions are motivated by interests and/or interplay them. 


\subsection{Technology and science as ideology: Habermas's work and ITS POTENTIAL INTERRELATION WITH THE PUBLIC COMMUNICATION OF SCIENCE}

Technology and Science as Ideology, published in 1968, is a debate with the central thesis that the German sociologist and philosopher Herbert Marcuse presented in One-Dimensional Man: Studies in the Ideology of Advanced Industrial Society. According to this thesis, science and technology began to play an ideological role in capitalist societies while concealing this role's underlying intention: class domination.

Habermas (1968) explains that Marcuse's critique of the concept of rationalization addressed by Max Weber is based on the fact that the latter does not investigate the nature of the domination that characterizes this rationalization, understood by Weber as advancing the process of applying rational decision criteria in the social spheres according to the rationality of capitalist economic activity and the bureaucratization undertaken by the bourgeoisie. For Marcuse, domination based on rationalization was legitimized by increased productivity and the domination of nature (resulting from technology and science), which provide comfort to individuals while mitigating questions and facilitating domination. Thus, the progressive rationalization of society would be dependent on the institutionalization of scientific and technical progress.

Habermas (1968) believes that Marcuse's thesis is the key to understanding that the liberal capitalism criticized by Marx has changed. Marx was critical of production relations as an instrument of domination and the ideology of just exchange. In a new phase, state interventionism demands a fresh look at these Marxist criticisms because the state had assumed the mission of ensuring social welfare and the "justice" of production and exchange relations. However, to legitimize this new political domination position, the state adopted an increasing interdependence with technical research, transforming the sciences into the leading productive force. The state's activity turned to the administrative resolution of technical tasks, eliminating public discussion, which resulted in the population's depoliticization. The exclusion of concern for practical issues related to social interaction left public opinion without any function. According to Marcuse's thesis, this depoliticization was enabled by scientization: it was sufficient to justify or legitimize specialized knowledge that adopted an ideological position for political decisions. 
It is at this point, Marcuse argues, that social evolution is determined by the logic of technical and scientific progress. The state's social compensations evoke the loyalty of the population and obfuscate the need for public discussion. Science and technology legitimize political decisions that do not undergo the scrutiny of public will formation. Technocracy (in which politicians and civil servants make decisions based exclusively on what experts say) is treated as an ideology, violating, according to Habermas (1968), one of the fundamental conditions of cultural existence: communication in a common language.

Challenging Marcuse's claim that science and technology are doomed to the service of class domination, Habermas (1968) undertakes the task of reformulating Weber's concept of rationalization. He demonstrates that it is necessary to make a differentiation. From a perspective of symbolically mediated interaction, rationalization involves emancipation and the extension of free communication. In contrast, a teleological-rational action system (instrumental and strategic) involves the growth of productive forces and extending the power of technical control. According to this understanding, the rationality of linguistic games, reconnected to communicative action, is confronted in modernity with the rationality of means-ends relations linked to instrumental and strategic action.

In rethinking the concept, Habermas (1968) therefore arrives at two perspectives for rationalization. One is at the level of rational action directed toward ends. The other is at the level of the institutional framework (communicative action). In this perspective, for science to contain something emancipatory, it cannot claim to replace communicative action, i.e., the debate on the pursuit of understanding, argumentation and thematization in the public sphere. "The redeeming power of reflection cannot be supplanted by the extension of technically exploitable knowledge" (HABERMAS, 1968, p. 16).

Habermas (1968) argues that technological progress depends on public investments. He states that while the optimistic assumption of convergence between technology and democracy is not acceptable, it is also impossible to accept the pessimism that technology excludes democracy. The author addresses three models of the relation between specialized and political knowledge: technocracy, decisionism and pragmatism. Only the latter necessarily refers to democracy. In decisionism, public opinion serves only to legitimize the leaders' decisions. Discussion by the public is not considered. 
In a technocracy, the formation of a democratic will becomes superfluous because it eliminates the public's participation.

With the pragmatist model,

[...] experts have not become sovereign over politicians subjected to the demands of the facts and left with a purely fictitious power of decision... Rather, reciprocal communication seems possible and necessary, through which scientific experts advise the decision-makers and politicians consult scientists in accordance with practical needs. (HABERMAS, 1968, p. 112).

In pragmatism, public opinion is a necessary mediator. Communication between politicians and scientists cannot be disconnected from existing social interests and value orientations. The communication of the pragmatist model makes political practice scientific. However, it does not exclude the permanent communication present in the pre-scientific phase. It is a communication that can be "institutionalized in the democratic form of public discussions among the citizen body. The relation of the sciences to public opinion is constitutive for the scientization of politics" (HABERMAS, 1968, p. 115). That is, "It is rather a question of setting into motion a politically effective discussion that rationally brings the social potential constituted by technical knowledge and ability into a defined and controlled relation to our practical knowledge and will” (HABERMAS, 1968, p. 105).

The argument is that the direction of technical progress remains determined by social interests. However, these interests are not the target of the reflective process because there is a certain pressure to reproduce current social life. This circumstance elicits a technical power that does not result in emancipation. New technologies are incorporated into everyday life without debates and reflections. Thus, researchers are often not concerned with how they will communicate their results to society for them to be debated because the customer knocking at the door of the study is someone interested in applying the research results to technology.

Habermas also introduces a reflection on the transit of scientific material between the life-world and science production institutions. Terming this process "translation" (a network of rational discussion extended between praxis and science), Habermas (1968) considers that it involves two challenges: the search for a solution to a practical problem identified in the social context, which he refers to as a context of discovery, and a need to bring the solution 
back to a problem situation deemed technically relevant to the location in which it will have practical consequences. This transit requires an interpretation of the scientific results that consider the initial problem situation.

Habermas (1968) even suggests that literature plays its role in this challenge of scientific information entering the life-world but clarifies that this is an issue to be solved by science; he is thus concerned with the question, "How is it possible to translate technically exploitable knowledge into the practical consciousness of a social life-world?" (HABERMAS, 1968, p. 96). The author considers that scientific information primarily enters the social life-world through its technical utilization (science that is transformed into technology and incorporated into the market). It is only through this utilization - if there is interest-that literature thematizes technology and science. One example is the poems about Hiroshima published after World War II.

Returning to factors that he considers to have helped in this "translation" process, Habermas (1968, p. 126) recalls that science has its own internal public opinion, nourished by scientific events and publications. A large number of publications required summaries and translations if the studies were to be more accessible, even to experts from other fields of knowledge. Habermas considers journalism in the following reflection: "Helmut Krauch is undoubtedly right in suspecting that in Germany, too, interchange among scientists is already dependent on scientific journalism extending from elaborately written reports to the scientific columns of the daily press" (HABERMAS, 1968, p. 125).

Habermas argues that the dialogue between science and politics can result in a long-term research policy from a more optimistic viewpoint. For this dialogue to occur, the discussions must win in the court of public opinion: "In the last analysis, the process of translation between science and politics is related to public opinion" (HABERMAS, 1968, p. 121). Habermas considers that neither the pressures from within the scientific process itself nor the demand for control from the outside would be sufficient to make the practical issues of scientific results the subject of public discussion. The genuinely decisive factor is the researchers themselves' initiative, who, in addition to being scientists are also citizens and should be committed to reflecting on what they produce.

According to Habermas (1968), the decision must be: will the a productive body of knowledge be merely transmitted to men engaged in technical manipulation for purposes of control, or will this knowledge be 
appropriated as the linguistic possession of communicating individuals? A scientized society could constitute itself as a rational one only to the extent that science and technology are mediated with the conduct of life through the minds of its citizens.

When we think about the popularization of science, nowadays, we notice that, even 50 years after Habermas expressed these reflections, we empirically realize that we have not evolved much towards a desirable relationship between science, public and politics. Research on the public perception of science in Brazil [CGEE, 2019] points to a lack of access to scientific knowledge by the public since the percentage of respondents who do not know the name of an institution that produces science is high $(88 \%)$ or a Brazilian scientist $(90 \%)$. We can still consider ourselves distant from the pragmatism that Habermas (1968) defends (political decisions taken from science and with the mediation of public opinion). In the context of the Covid-19 pandemic, in 2020, with so many political decisions that deviated from science recommendations, we could risk saying that we are still very close to decisionism. Based on this scenario, studies on the popularization of science and public communication of science have many questions to dedicate themselves to, and this work by Habermas awakens us to many questions, which deserve future investigations.

We must know if the results of science and technology have passed through the scrutiny of the formation of public will, through the mediation of language, from public debate. What weight has been attributed to rationalities (communicative and strategic) in popularizing science processes. How has communication between politicians/legislators and scientists occurred, and whether these means of communication are accessible and open to public opinion. What has been the relationship between the potential of "scientific knowledge" and "practical knowledge and will" as the transit of material between the world of life and scientific production occurs today. What has been the role of scientific journalism and other languages in the "translation" of knowledge scientific. What is the position of researchers concerning the dilemma of being both citizens and scientists.

These are questions that arise from a careful reading of the book and that, even today, demand numerous theoretical and empirical studies if we are to outline good answers. In any case, they help us conceive of the popularization of science as a complex and challenging object of study and perceive the extent to which Habermas's reflections play a role in raising these questions. 


\subsection{TOWARD A RATIONAL SOCIETY: DEMOCRATIZED UNIVERSITIES AND REFLECTIVE PROCESSES OF SCIENCE/PUBLIC DISCUSSION}

Toward a Rational Society was initially published in 1969 and is an argument for the democratization of universities. Several passages coincide with ideas addressed in "Technology and Science as Ideology." The author argues that the sciences must practice critical self-reflection, citing several examples of how researchers can become critically aware of their assumptions:

I consider it philosophical enlightenment when doctors learn from sociological and psychoanalytic studies to appreciate the influence of the family environment in the genesis of psychoses and thereby also learn to reflect on certain biologistic assumptions of the tradition of their discipline. (HABERMAS, 1989, p. 8).

He states that this self-reflection is also essential to the process of transposing scientific results to the life-world.

Only in it can we bring to consciousness, through reflection, the relation of living generations to active cultural traditions, which otherwise operate dogmatically. Finally, only in it can we subject to critical discussion both attitudes of political consequence and motives that form the university as a scientific institution and a social organization. Students' participation in research processes essentially includes participation in this self-reflection of the sciences (HABERMAS, 1989, p. 9).

For Habermas (1989), the presence of rationalization is consistent with a politicized university. He does not believe in the necessary opposition between a university aimed at professional specialization and one that seeks politicization; both functions should coincide. It is a question of seeing the university, not as a place for political decisions but for discussing political issues that follow the same rules as scientific productions' rationality. Habermas believes that it is essential to include students in the university's critical discussion of practical issues.

Habermas (1989) also argues that technological progress's undesirable consequences lead humanity to pursue its social destiny and control it. To this end, it is necessary to introduce a politically effective discussion that considers both the social potential constituted by technical knowledge and ability and practical will. This discussion can lead those who act politically to judge, practically and based on their self-interpreted needs, the direction 
and the extent to which they want to develop technical knowledge for the future. Similarly, the irrationality of domination can be mastered by a political decision-making process linked to the principle of general discussion free from domination.

When addressing the scientization of politics, Habermas did not identify it as a reality but rather as an observable tendency. Many research studies are performed at government agencies, and that scientific information is increasingly consulted in the public services, particularly by the military and bureaucrats. He notes that the successful transposition of technical recommendations into practice is, in the pragmatic model, dependent on mediation by the public. Practical needs must be understood if they serve as a foundation for the technical progress that emerges from communication between experts and decision-makers. It is a communication that must be rooted in the social interests and value orientations of the life-world. The pragmatist model's communication presupposes the consideration of the communication that occurs on the pre-scientific level, which can be institutionalized in public discussions. "The relation of the sciences to public opinion is constitutive for the scientization of politics," writes Habermas (1989, p. 69).

However, Habermas admitted that empirical conditions for applying the pragmatist model were lacking because of factors such as the depoliticization of the masses and the decline of the public domain, which are part of a system of domination that excludes practical issues from public discussion (i.e., the public domain is restricted to spectacles and acclamation mediated through communication). However, Habermas (1969) continued to address the true challenge of the dialogue between science and politics: the formulation of a long-term research policy that would prevent unplanned relations between technical progress and the social life-world.

When we think about the popularization of science today, the discussions of this work lead us to reflect on universities' role as producers of knowledge in Brazil. Due to the scientific research they carry out, they would also have the mission of sharing this knowledge with society, subjecting it to the sieve of public conversations and promoting the self-reflection of the sciences within their broad academic communities critical discussion of knowledge produced. Again, we are faced with scenarios to be investigated by studies on the popularization of science: it is vital to know how much scientific research produced in universities is disseminated and discussed 
internally, including the participation of students and other members of the academic community.

\subsection{SYNTHESIS OF THE CONTRIBUTIONS THAT CAN BE EXTRACTED FROM THE THREE WORKS OF HABERMAS TO THINK ABOUT AND THE PUBLIC COMMUNICATION OF SCIENCE}

From the reflections extracted from the three works discussed here, considering their aspects that refer to communication about science in society, we consolidate the information and interrelate it in a schematic representation that can guide the proposal of possible public policies to encourage communication science, as well as awakening to new research problems to be studied on the topic (Figure 1).

Figure 1. Schematic representation of the synthesis produced, based on three works by Habermas, about essential considerations for thinking about public communication of science

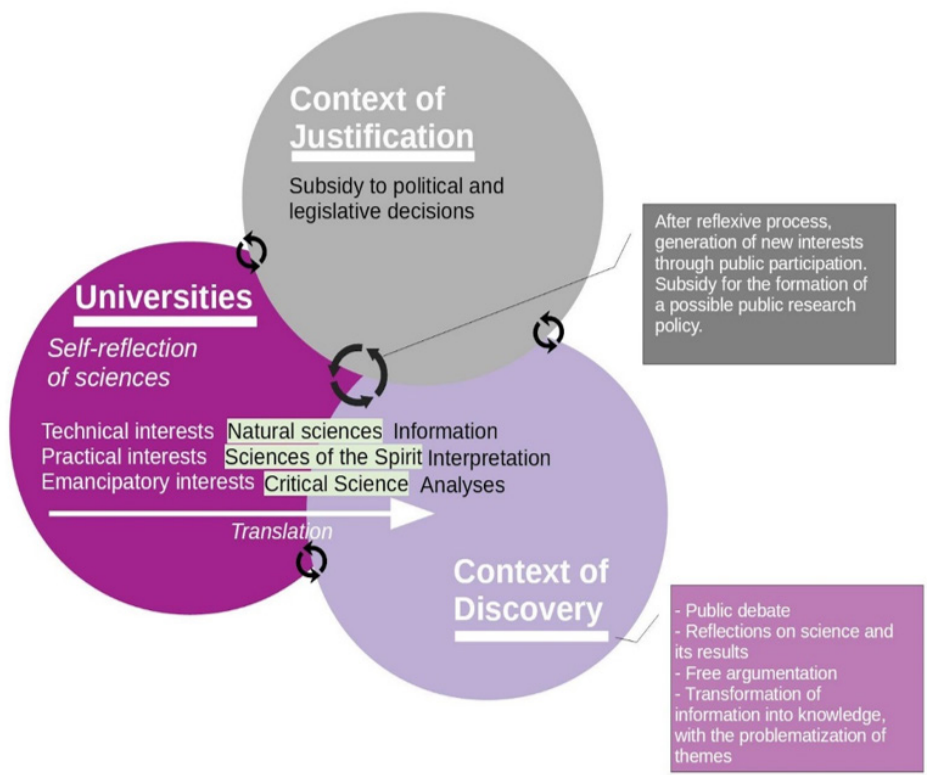

Prepared by the authors, based on Habermas (1968, 1987, 1989) 
This flow considers that the university must be a democratic space for scientific knowledge production, where the sciences' self-reflection must occur. The production of knowledge must be considered motivated by different interests (technical, practical and emancipatory), captured in the context of discovery (the world of everyday social life). They are then themed in studies that must necessarily go through - even in the academic environment - through self-reflection. Through the process that Habermas called "translation", and which we treat as the popularization of science or public communication of science, the information, interpretations, and analyses generated by the studies need to be shared with society. In this way, they can return to the context of discovery and pass public debate scrutiny to become part of social knowledge. As such, they can support political and legislative decisions in the context of justification and/or generate new collective interests. In turn, these new collective interests must return to the base of operations in the academic world, covered by the interpretations and critical analyzes necessary for social transformation. In general, this process represents a continuous circular movement that, over time, tends to a science building with effective social participation. Thus, popularization is an essential part of this process.

Different research questions may emerge when light is cast on any event in this flow, as in Germano and Kulesza (2007), Stilgoe and Wilsdon (2014), Jasanoff (2014), Molek-Kozakowsk (2017), Makarovs and Achterberg (2018), Katz-Kimchi (2012), Crick and Gabriel (2010) and many others who have contributed to reflection on this topic. Together, these studies generate reflections and seek answers that might one day provide a solid foundation for progress toward the effective functioning of a desirable flow for science's public communication.

\section{Final Considerations}

We have sought to offer a theoretical contribution to researchers studying science's public communication based on the relevance of three texts by Habermas to different areas of knowledge and objects of study. Habermas's views in these three texts that address topics directly related to the present challenges of science popularization facilitate that organization of his ideas into a representation of the dynamic to be considered in these communication processes with the society about scientific knowledge. This representation enables several different questions to be raised, including those 
related to the obstacles to the desired dynamic's entire operation to the science popularization.

Habermas's potential contributions to this field of study are not only found in the three works we discuss. On the contrary, the texts analyzed here are only part of a rich and valuable theoretical output on science's public communication, particularly concerning the public sphere and communicative action theory.

The author also has other recent productions that can contribute to reflections on science communication in society, such as "The future of human nature", the result of conferences he presented in the early 2000s. However, the study presented in this article proposed a cut based on three works produced more than 50 years ago and which can still provide interesting reflections to think about the communication of science in society, which already contained the embryo of ideas that the author develops later. This analysis does not exclude the fact that we consider how much other excerpts on the production of Habermas, to be covered in other articles, are essential to explore all the contribution that the author can provide to the theme.

In sum, the discussed works call our attention to the following aspects: a) the university as a democratic space for the production of scientific knowledge, where there must be self-reflection on the knowledge produced, an ethical commitment from researchers to society when performing their studies and independence from powers contrary to the public interest; b) contact between academia and the social world of everyday life; the latter is the context of discovery from which interests emerge that guide the development of research and to which information and knowledge must return for public consideration and debate through communicative rationality, which mediates; c) a context of justification, in which political decisions are made and laws are formulated based on a science that has undergone critical reflection and analysis by public opinion; and d) the need for the whole debate to be based on the consideration of the three types of interests that mobilize the production of knowledge - technical, practical and emancipatory.

This dynamic's operation has potential for social transformation because it would facilitate changing the interests that generate knowledge, benefiting the public interest and scientific practice itself. In the long term, such a change would enable the democratic and participatory construction of 
research policy by including the public in developing the scientific agenda and promoting forums for interaction among citizens, scientists and legislators.

ALVIM-SILVA, A. E. F.; PEREIRA, J. R.; AGUIAR, C. M. G. Algumas contribuiçóes de Habermas para o estudo da comunicação pública da ciência. Trans/form/ação, Marília, v. 44, n. 4, p. 21-44, Out./Dez., 2021.

Resumo: Este ensaio teórico explora três publicaçôes de Jürgen Habermas da década de 1960, nas quais o autor trata da crítica da ciência, da produção do conhecimento e da democratização das universidades. O objetivo foi extrair delas recortes de reflexóes que podem contribuir para os estudos da comunicação pública da ciência. Consolidam-se as reflexões em uma representação gráfica que resume os fatores a serem considerados, ao se pensar a prática de comunicação da ciência, na sociedade: a importância de levar em conta os três interesses que movem a produção do conhecimento - técnico, prático e emancipatório -, de promover a autorreflexão das ciências em universidades politizadas e democratizadas, e de haver a mediaçáo da sociedade na interação entre ciência e política, de forma a subsidiar a tomada de decisóes com base em interesses sociais. Argumenta-se que as bases para uma ideia de comunicação pública da ciência dialógica - hoje amplamente defendida - despontaram no pensamento do filósofo alemão, em livros publicados há mais de 50 anos, embora essa não fosse sua motivação central, naquele momento.

Palavras-chave: Comunicação Pública da Ciência. Jürgen Habermas. Participação Social. Decisões Políticas.

\section{REFERENCES}

BAUER, M. W.; GREGORY, J. From journalism to corporate communication in postwar Britain. In: BAUER, M; BUCCHI, M. (ed.). Journalism, science and society: science communication between news and public relations. New York, NY: Routledge, 2007. p. 33-51.

BRANDÃO, E. Conceito de Comunicação Pública. In: DUARTE, J. (org).

Comunicaçáo pública: Estado, Mercado e Interesse Público. São Paulo: Atlas, 2007. p. $1-33$.

BURNS, T. W.; O'CONNOR, D. J.; STOCKLMAYER, S. M. Science Communication: A Contemporary Definition. Public Understanding of Science, v. 12, n. 2, p. 183-202, 2003. doi: 10.1177/09636625030122004.

CGEE - Centro de Gestão e Estudos Estratégicos. Percepção pública da C\&T no Brasil. 2019. Brasília, 2019. Retrieved from: https://www.cgee.org.br/web/percepcao. 
CRICK, N.; GABRIEL, J. The Conduit Between Lifeworld and System: Habermas and the Rhetoric of Public Scientific Controversies. Rhetoric Society Quarterly, v. 40, n. 3, p. 201-223, 2010. doi: 10.1080/02773941003614464.

DE LIMA, C. M. Agir Comunicativo, Trabalho Imaterial e Sociedade da Informação. In: PINZANI, A; DE LIMA, CM; DUTRA, DV. (org.), O pensamento vivo de Habermas. Florianópolis, SC: Nefipo, p. 99-113, 2009. Retrieved from: http://ridi.ibict. $\mathrm{br} /$ handle/123456789/982.

DIETZ, T. Bringing values and deliberation to science communication. Proceedings of the National Academy of Sciences of the United States of America, v. 110, n. 3, p. 14081-14087, 2013. doi: 10.1073/pnas.1212740110.

ENTRADAS, M. et al. Public communication by research institutes compared across countries and sciences: Building capacity for engagement or competing for visibility? PLoS ONE, Spain, v. 15, n. 7, July 2020. doi: https://doi.org/10.1371/journal. pone.0235191.

FAIRCLOUGH, N.; FAIRCLOUGH, I. Polytical Discourse Analysis: a method for advanced students. London: Routledge, 2012.

FRIESIKE, S. et al. Setting up crowd science projects. Public Understanding of Science, v. 27 , n. 5, p. 515-534, 2016. doi: 10.1177/0963662516678514.

GERMANO, M. G.; KULESZA, W. A. Popularização da Ciência: uma revisão conceitual. Caderno Brasileiro de Ensino de Física, v. 24, n. 1, p. 7-25, 2007. doi: 10.5007/\%25x.

GREGORY, J. et al. Public engagement of science in the private sector A new form of PR? In: BAUER, M.; BUCCHI, M. (ed). Journalism, science and society: science communication between news and public relations. New York, NY: Routledge, 2007. p. 203-213.

HABERMAS, J. Técnica e ciência como ideologia [Technology and Science as Ideology] (A. Morão, Trans.). Lisboa: Ediçóes 70, 1968.

HABERMAS, J. Conhecimento e interesse [Knowledge and Human Interests] (J. N. Heck, Trans.). Rio de Janeiro: Guanabara, 1987.

HABERMAS, J. Toward a Rational Society: Student Protest, Science and Politics. Cambridge: Polity Press, 1989.

HABERMAS, J. Depois de trinta anos: notas acerca de Conhecimento e Interesse [Nach dreißig Jahren: Bemerkungen zu Erkenntnis und Interesse] (MJ Wesseling, Trans.) Problemata, v. 2, n. 2, p. 332-341, 2011. Retrieved from: https://dialnet.unirioja.es/ descarga/articulo/3834919.pdf.

HABERMAS, J. Teoria do Agir Comunicativo (v. 2) [The theory of communicative action] (FB Siebeneichler. Trans.). Sáo Paulo: Martins Fontes, 2012. 
JASANOFF, S. A mirror for science. Public Understanding of Science, v. 23, n.1, p. 21-26, 2014. doi: 10.1177/0963662513505509?journalCode=pusa.

KATO-NITTA, N. et al. Understanding the public, the visitors, and the participants in science communication activities. Public Understanding of Science, v. 27, n. 7, p. 857 875, 2018. doi: 10.1177/0963662517723258.

KATZ-KIMCHI, M. Screening Science, producing the nation: popular Science programs on Israeli television 1968-88. Media, Culture \& Society, v. 34, n. 5, p. 519-536, 2012. doi: $10.1177 / 0163443712442699$.

MAKAROVS, K.; ACHTERBERG, P. Science to the People: A 32-nation survey. Public Understanding of Science, v. 27, n. 7, p. 876-896, 2018. doi: $10.1177 / 0963662517754047$.

MASSARANI, L.; MOREIRA, I. C. Science communication in Brazil: A historical review and considerations about the current situation. Academia Brasileira de Ciências, v. 88, n. 3, p. 1577-1595, 2016. doi: 10.1590/0001-3765201620150338.

MENKES, M. As políticas públicas para popularização da ciência no Brasil [Paper presentation]. Simpósio regional de jornalismo científico no Centro-Oeste, Brasília, Brazil, October 2012.

MOLEK-KOZAKOWSK, K. Stylistic analysis of headlines in science journalism: A case study of New Scientist. Public Understanding of Science, v. 26, n. 8, p. 894-907, 2017. doi: 10.1177/0963662516637321?journalCode=pusa.

MYERS, G. Discourse Studies of Scientific Popularization: questioning the boundaries. Discourse Studies, v. 5, n. 2, p. 265-279, 2003. doi: 10.1177/1461445603005002006.

NISBET, M. C.; SCHEUFELE, D. What's next for science communication? Promising directions and lingering distractions. American Journal of Botany, v. 96, n. 10, p. 17671778, 2009. doi: 10.3732/ajb.0900041.

NOBRE, H. H.; GIL, P. G. Uma rota para teoria e prática em comunicação pública: a argumentação como luta cívica por reconhecimento, respeito e justiça. In: MARQUES, Â; OLIVEIRA, I. L; LIMA, F. (org.). Comunicaçáo Organizacional: vertentes conceituais e metodológicas. Belo Horizonte: PGCOM UFMG, 2017. v. 2, p. 101-118.

OWENS, S.' Engaging the public': Information and deliberation in environmental policy. Environment and Planning A, v. 32, n. 7, p. 1141-1148, 2000. doi: 10.1068/a3330.

PAES DE PAULA, A. P. Para Além dos Paradigmas nos Estudos Organizacionais: O Círculo das Matrizes Epistemológicas. Cadernos Ebape, v. 14, n. 1, p. 24-46, 2016. doi: 10.1590/1679-395131419.

PIECZKA, M.; ESCOBAR, O. Dialogue and science: Innovation in policy-making and the discourse of public engagement in the UK. Science and Public Policy, v. 40, n. 1, p. 113-126, 2012. doi: 10.1093/scipol/scs073. 
RÖDDER, S. Science Media Centres and Public Policy. Science and Public Policy, v. 42, n. 3, p. 387-400, 2015. doi: 10.1093/scipol/scu057.

SILVA, A. E. F. A. A ciência em circulação nas esferas públicas: o jornalismo científico em universidades de Minas Gerais e suas repercussóes. 2019. 328 p. (PhD Thesis in Administration) - Universidade Federal de Lavras, Lavras, MG, 2019.

STILGOE, J.; LOCK, S; WILSDON, J. Why should we promote public engagement with science? Public Understanding of Science, v. 23, n. 1, p. 4-15, 2014. doi: 10.1177/0963662513518154.

Recebido: 22/11/2020

Aceito: $15 / 4 / 2021$ 